Article

\title{
In situ doping brushite on zinc manganese oxide toward enhanced water oxidation performance: Mimicry of an oxygen-evolving complex
}

\author{
Miao Jiang, Junying Chen *, Yingwei Li \# \\ State Key Laboratory of Pulp and Paper Engineering, School of Chemistry and Chemical Engineering, South China University of Technology, Guangzhou \\ 510640, Guangdong, China
}

\section{A R T I C L E I N F O}

\section{Article history:}

Received 4 February 2018

Accepted 22 March 2018

Published 5 June 2018

\section{Keywords:}

Zinc manganese oxide

Brushite

Metal-organic frameworks

Water oxidation

Oxygen-evolving complex

\begin{abstract}
A B S T R A C T
We report in situ doping of brushite on zinc manganese oxide (ZMO), fabricated by calcining a Mn(II) oxalate-impregnated metal-organic framework. The doping process was conducted in combination with the photocatalytic water oxidation reaction which was catalyzed by ZMO in neutral phosphate-buffered aqueous solution containing $\left[\mathrm{Ru}(\mathrm{bpy})_{3}\right]^{2+}-\mathrm{Na}_{2} \mathrm{~S}_{2} \mathrm{O}_{8}$ and calcium(II) triflate salt, exhibiting greatly enhanced water oxidation performance with optimized turnover frequency of $0.18 \mathrm{mmol}_{02} \mathrm{~mol}_{\mathrm{Mn}^{-1}} \mathrm{~s}^{-1}$. Different analytical techniques indicated that photodeposited calcium-phosphate ( $\mathrm{CaP}$ ) acted as a co-catalyst to promote the $\mathrm{O}_{2}$ evolution activity of ZMO. This system involved the use of manganese oxide and calcium ion, and the operation was conducted under ambient temperature and neutral conditions, thus, it efficiently mimicked the oxygen-evolving complex in photosystem II.
\end{abstract}

(C) 2018, Dalian Institute of Chemical Physics, Chinese Academy of Sciences. Published by Elsevier B.V. All rights reserved.

\section{Introduction}

Producing renewable and clean energy is regarded as an effective strategy for meeting the energy needs of present and future generations [1]. Sunlight is the only source that provides sustainable and carbon-neutral energy to reduce the stress from the shortage of fossil fuels and environmental crises caused by the use of fossil fuels [2]. Consequently, researchers have long been focusing on the conversion and utilization of solar energy. One of the most promising strategies in pursuit of such ideal energy is water splitting to produce $\mathrm{H}_{2}$ by either photo-induced routes or electronic techniques [3-10]. Howev- er, a key challenge limiting the improvement of overall water splitting efficiency is the complicated and sluggish water oxidation reaction that involves the $4 \mathrm{H}^{+} / 4 \mathrm{e}^{-}$oxidation of two water molecules to dioxygen. Meanwhile, an efficient catalyst must tolerate the harsh conditions for water oxidation (i.e., sufficient power), under which most functionalized moieties lose their activities for sustained water splitting [11]. In natural photosynthesis, sunlight is converted and stored via an oxygen-evolving complex (OEC) in photosystem II (PS II), which contains a $\mathrm{Mn}_{4} \mathrm{CaO}_{5}$ cluster surrounded by protein matrixes $[12,13]$. Inspired by nature's wisdom, numerous efforts have been devoted to developing an efficient artificial photosynthe-

\footnotetext{
* Corresponding author. Tel: +86-20-87113656; E-mail: chenjunying2010@sina.com

\# Corresponding author. Tel: +86-20-87113656; E-mail: liyw@scut.edu.cn

This work was supported by the National Natural Science Foundation of China $(21436005,21576095,21706078)$, Fundamental Research Funds for the Central Universities (2017PY004, 2017MS088), the State Key Laboratory of Pulp and Paper Engineering (201710, 2017ZD04), China Postdoctoral Science Foundation (2016M590771, 2017T100625), Guangdong Natural Science Foundation (2016A050502004, 2016A030310413, 2017A030310029, 2017A030312005), and Science and Technology Program of Guangzhou (201804020009).

DOI: 10.1016/S1872-2067(18)63075-X | http://www.sciencedirect.com/science/journal/18722067 | Chin. J. Catal., Vol. 39, No. 6, June 2018
} 
sis system [14-19], especially where manganese oxide and calcium ions are involved. Mn chemistry exhibits multiple oxidation states and is capable of the Kok cycle of the natural PS II system. $\mathrm{Ca}^{2+}$ is widely recognized as a weak Lewis acid promoting the proton-coupled electron transfer (PCET) process between proteins and Mn-Ca cluster, and/or as the binding site for water molecular substitution [20]. In biomimetic studies, plenty of chemists have endeavored to develop calcium manganese oxide $\left(\mathrm{CaMnO}_{x}\right)$-based systems, giving solid evidence for improved catalytic activity through the incorporation of $\mathrm{Ca}^{2+}$ in Mn oxides [20]. Li et al. [21] fabricated nanostructured non-crystalline $\mathrm{CaMnO}_{x}$ showing enhanced activity in water oxidation reactions for both chemical and photocatalytic systems. This work demonstrated that the disordered structure of $\mathrm{CaMnO}_{x}$ and a modest valence state of Mn were important factors for achieving high water oxidation activity. Several reports have provided similar insights into the relevance of highly crystalline structures of Mn oxides and their lower efficiencies in water oxidation compared to those of amorphous phases. Kurz and coworkers [22] synthesized layered Mn oxides containing a series of alkaline earth cations, e.g., $\mathrm{K}, \mathrm{Ca}, \mathrm{Sr}$, and $\mathrm{Mg}$. That with Ca incorporated reached the highest catalytic activity. Thapper's work studied the influence of phosphate ion on the construction of Mn oxide structures and valence state of Mn [23]. Considering the Angström-scale $\mathrm{Mn}_{4} \mathrm{CaO}_{5}$ cluster in OEC [24], the preparation of different phases of Ca-Mn oxides with ultra-small size and their use in photocatalytic water oxidation under neutral conditions would be of great interest.

In addition, metal-organic frameworks (MOFs) represent a class of coordination polymers with inherent features like ultrahigh porosity, enormous internal surface area, and flexibility [25-28]. Calcinating MOFs in atmosphere could afford neat metal oxides or metal oxides embedded in carbon matrices derived from organic units, owing to the periodical assembly of metal nodes and organic linkers in the frameworks. The resulting metal oxides may inherit some advantages from the pristine MOF such as enlarged surface area or ordered structures and thus exhibit excellent performances in various applications including catalysis, adsorption, as well as energy-related areas [29,30]. To the best of our knowledge, the use of MOF-templated transition metal oxides, especially Mn oxides, as photocatalysts for light-driven water oxidation has seldom been studied. Moreover, calcium-phosphate (CaP) including brushite is a class of inorganic minerals and normally non-toxic to living beings and the environment [31-34]. Their effects on water splitting reactions have not been studied before.

Herein, we report the design and synthesis of a MOF-templated Zn-Mn oxide (ZMO)-catalyzed water oxidation system to verify the role of calcium ion. The catalytic performances of photochemical water oxidation in phosphate-buffered neutral aqueous solution containing $\left[\mathrm{Ru}(\mathrm{bpy})_{3}\right]^{2+}$ and $\mathrm{S}_{2} \mathrm{O}_{8}{ }^{2-}$ were found to be 10 -fold higher when the reaction was carried out in the presence of $\mathrm{Ca}^{2+}$ in comparison with those in the absence of $\mathrm{Ca}^{2+}$. CaP was deposited in situ on ZMO during the photocatalytic reaction and played a key role in boosting the water oxidation reaction. Control experi- ments with prolonged irradiation time demonstrated increased CaP contents in the resulting materials, which essentially influenced the catalytic activity. The ZMO material doped CaP in situ and its use in light-driven water oxidation involved the use of earth-abundant elements, ambient temperature, and neutral conditions, and thus could be regarded as an efficient functional model for OEC.

\section{Experimental}

\subsection{General}

Commercially available chemicals and reagents involved in this study were purchased from Shanghai Aladdin Reagent Co. Ltd and Macklin Biochemical Co. Ltd, China, and used without further purification unless otherwise indicated. $\mathrm{Ru}(\mathrm{bpy})_{3}\left(\mathrm{PF}_{6}\right)_{2}$ (bpy $=2,2$ '-bipyridine) was purchased as chloride salt and metathesized in water by precipitation with excess $\mathrm{NH}_{4} \mathrm{PF}_{6}$. The orange solid obtained was further recrystallized with ether from a minimum volume of acetone solution.

\subsection{Synthesis}

ZIF-8 was prepared according to the literature with a few modifications [35]. Typically, $\mathrm{Zn}\left(\mathrm{NO}_{3}\right)_{2} \cdot 6 \mathrm{H}_{2} \mathrm{O}(22.6 \mathrm{mmol}, 6.7 \mathrm{~g})$ was dissolved in $160 \mathrm{~mL}$ methanol. Another $160 \mathrm{~mL}$ methanolic solution containing 2-methylimidazole (180.3 mmol, $14.8 \mathrm{~g}$ ) was added to the above solution with vigorous stirring. The mixture solution was kept stirring for $24 \mathrm{~h}$. All operations were performed at room temperature. The product was separated by centrifugation and thoroughly washed twice with methanol, and finally dried at $50{ }^{\circ} \mathrm{C}$ overnight in a drying oven. The obtained ZIF-8 powders were further activated at $100{ }^{\circ} \mathrm{C}$ under vacuum for $10 \mathrm{~h}$ prior to use.

Zinc-manganese oxides (ZMOs) were synthesized by a conventional impregnation method followed by MOF-templated calcination. In a typical synthesis of ZMO, manganese(II) oxalate dehydrate $(0.5 \mathrm{~g})$ was dissolved in $20 \mathrm{~mL}$ ethanol. ZIF-8 powder $(0.5 \mathrm{~g})$ was added to the above solution. After stirring at room temperature for $2 \mathrm{~h}$, the product was separated by centrifugation and washed thoroughly with ethanol and water. The resulting powders were dried in an oven at $80{ }^{\circ} \mathrm{C}$ overnight. After that, two-stage calcination was performed to obtain ZMO. The dry powders were first annealed at $400{ }^{\circ} \mathrm{C}$ for $8 \mathrm{~h}$ in nitrogen at a heating rate of $2{ }^{\circ} \mathrm{C} \mathrm{min}-1$ and cooled to room temperature. Then, the thermolysis temperature was elevated to $600{ }^{\circ} \mathrm{C}$ with the same heating program and maintained for 3 $\mathrm{h}$ in air flow. After cooling to ambient temperature, the produced powders were collected, dispersed in $\mathrm{NH}_{4} \mathrm{Cl}-\mathrm{NH}_{3} \cdot \mathrm{H}_{2} \mathrm{O}$ (5-2.5 mol L-1) aqueous solution to remove excess $\mathrm{ZnO}$, and washed with water. The final product was obtained after drying overnight in an oven at $80{ }^{\circ} \mathrm{C}$. In addition, a series of ZMOs were prepared using the same procedure, changing only the time of the second calcination stage from 2 to $5 \mathrm{~h}$ or the amount of $\mathrm{Mn}$ oxalate from 0.1 to $0.7 \mathrm{~g}$ to obtain ZMOs with varied $\mathrm{Zn} / \mathrm{Mn}$ ratios.

$\mathrm{Mn}_{2} \mathrm{O}_{3}$-syn was synthesized according to the literature [36]. 
$\mathrm{Mn}_{2} \mathrm{O}_{3}-1$ was synthesized by calcinating $\mathrm{Mn}$ oxalate using the thermolysis program described for $\mathrm{ZMO} . \mathrm{Zn}_{x} \mathrm{Mn}_{y} \mathrm{O}_{z}$ was obtained by mixing zinc nitrate and manganese oxalate in the same ratio as that of $\mathrm{ZMO}$, followed by thermolysis treatment using the heating program described above. The as-formed powders were dispersed in an $\mathrm{NH}_{4} \mathrm{Cl}-\mathrm{NH}_{3} \cdot \mathrm{H}_{2} \mathrm{O}(5-2.5$ mol L-1) aqueous solution to remove possible $\mathrm{ZnO}$ and washed with water repeatedly.

\subsection{Procedures of photocatalytic water oxidation and in situ doping brushite during the photocatalysis test}

Photocatalytic oxygen evolution experiments were performed in a Labsolar-III AG photocatalysis system connected to gas chromatograph (GC, TECHCOMP 7900), which was equipped with a thermal conductivity detector (TCD) and a $5 \AA$ molecular sieve column. Such tests were conducted in a 300-mL quartz reaction vessel containing $20 \mathrm{mg}$ catalyst, 10 $\mathrm{mmol} \mathrm{L}^{-1} \mathrm{Na}_{2} \mathrm{~S}_{2} \mathrm{O}_{8}, 2 \mathrm{mmol} \mathrm{L}-1 \mathrm{Ru}(\text { bpy })_{3}\left(\mathrm{PF}_{6}\right)_{2}$, and $10 \mathrm{mmol} \mathrm{L}^{-1}$ $\mathrm{Ca}\left(\mathrm{CF}_{3} \mathrm{SO}_{3}\right)_{2}$ in $100 \mathrm{~mL}$ phosphate buffer $\left(0.25 \mathrm{~mol} \mathrm{\textrm {L } ^ { - 1 }}\right.$ $\mathrm{Na}_{2} \mathrm{HPO}_{4}-\mathrm{NaH}_{2} \mathrm{PO}_{4}$ aqueous solutions, $\mathrm{pH} \sim 7$ ). Reaction temperature was maintained using a low-temperature circulator at $25{ }^{\circ} \mathrm{C}$. Reactants in the quartz vessel were degassed under vacuum for 20 min to remove all dissolved oxygen from the aqueous solution before doing the experiments. The quartz vessel was then irradiated from the top window with a continuous output Xe lamp (300 W, Microsloar 300). The amounts of $\mathrm{O}_{2}$ evolved were determined by external standard method either through online GC injection process every $30 \mathrm{~min}$ or by manual injection of a quantified gas phase from the headspace of the reactor every 5 min with high purity argon gas as carrying gas. CaP was deposited on ZMO catalyst during the photocatalytic reaction. After one cycle of the photocatalysis test, the catalyst was collected and washed with acetone and deionized water repeatedly, and dried overnight at $80^{\circ} \mathrm{C}$. The final material was denoted ZMO-insitu.

\subsection{Photodeposition of brushite on ZMO before water oxidation test}

The photodeposition of brushite before the water oxidation test was executed by the irradiation of a solution containing 20 mg ZMO and $10 \mathrm{mmol} \mathrm{L}^{-1} \mathrm{Ca}\left(\mathrm{CF}_{3} \mathrm{SO}_{3}\right)_{2}$ in $100 \mathrm{~mL}$ phosphate buffer $\left(0.25\right.$ mol L-1 $\mathrm{Na}_{2} \mathrm{HPO}_{4}-\mathrm{NaH}_{2} \mathrm{PO}_{4}$ aqueous solutions, $\mathrm{pH}$ 7) for a certain time (e.g., 15, 30, 45, and $60 \mathrm{~min})$. The catalyst, denoted CaP@ZMO- $x(x=15,30,45$, and 60), was filtered, washed with acetone and deionized water, and dried overnight at $80{ }^{\circ} \mathrm{C}$. The amounts of $\mathrm{CaP}$ doped on ZMO were normalized to the Ca contents in the as-formed materials by AAS. To confirm that the deposition was induced by photo-irradiation, this procedure was also performed in the dark. The resulting material, denoted CaP@ZMO-0, was collected, washed, dried, and characterized.

\subsection{Characterization}

Powder X-ray diffraction (XRD) patterns of the samples were recorded on a Rigaku diffractometer (D/MAX/IIIA, $3 \mathrm{~kW}$ ) using $\mathrm{Cu}-K_{\alpha}$ radiation $(40 \mathrm{kV}, 30 \mathrm{~mA}, \lambda=0.1543 \mathrm{~nm}$ ). Thermogravimetric (TG) curves were recorded on an SDT-Q600 instrument from room temperature to $900{ }^{\circ} \mathrm{C}$ at a heating rate of $10{ }^{\circ} \mathrm{C} \mathrm{min}-1$ under air flow. The zinc, manganese, and calcium contents in each sample were measured quantitatively by atomic absorption spectroscopy (AAS) using a HITACHI Z-2300 instrument. The BET surface areas and pore sizes were obtained from the $\mathrm{N}_{2}$ adsorption-desorption isotherms measured on a Micromeritics ASAP $2020 \mathrm{M}$ instrument at $-196^{\circ} \mathrm{C}$. Before the measurements, the samples were degassed at $100{ }^{\circ} \mathrm{C}$ for 6 h. X-ray photoelectron spectroscopy (XPS) measurement was performed using a Kroatos Axis Ultra DLD system with base pressure of $10^{-9}$ Torr. The surface morphologies of the materials were investigated using a high-resolution scanning electron microscope (SEM, MERLIN of ZEISS) equipped with an energy dispersive X-ray spectrometer (EDS). The structure and elemental distribution were determined with a high-resolution transmission electron microscope (TEM, JEOL, JEM-2100F) with an EDX analysis system (Bruker Xflash 5030T) operated at $200 \mathrm{kV}$.

\section{Results and discussion}

\subsection{Characterization of the corresponding materials}

MOF-templated synthesis of ZMO is illustrated in Scheme 1. The pristine MOF, ZIF-8, was prepared according to literature from the reaction of $\mathrm{Zn}^{2+}$ and 2-methylimidazole. The successful formation of dodecahedral ZIF-8 with smooth rhombic surfaces and mean particle size of around 200-300 nm was confirmed from SEM images and XRD patterns (Fig. 1) [35]. Its thermal behavior was measured by TG, which suggested a well-maintained MOF structure until the thermolysis temperature was above $400^{\circ} \mathrm{C}$ in air (Fig. S1).

After a conventional impregnation procedure with manganese oxalate, the resulting material was calcined using a two-stage temperature-elevating program. The product from the first stage was analyzed by XRD and TEM measurements, showing similar XRD patterns as that of pristine ZIF-8 (Fig. S2) and well-preserved dodecahedral morphology with some perceived particles on the surfaces (Fig. S3(a)). High-resolution TEM (HRTEM) image of these particles revealed an interplanar

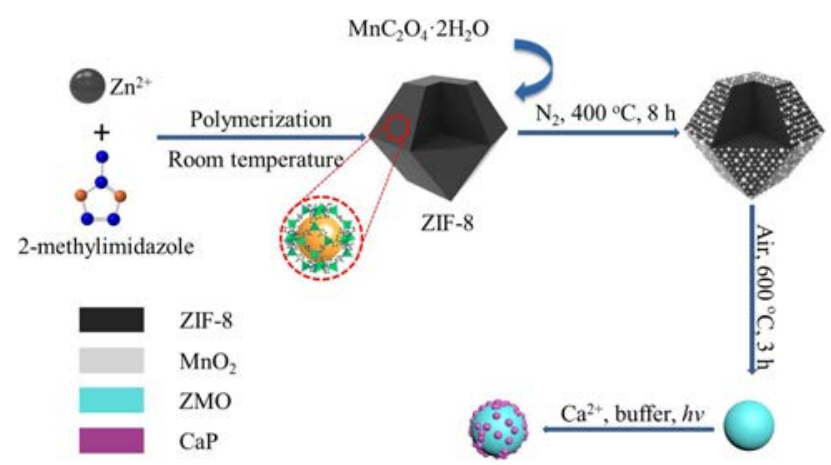

Scheme 1. Schematic illustration of the preparation of ZMO and in situ doping of CaP. 

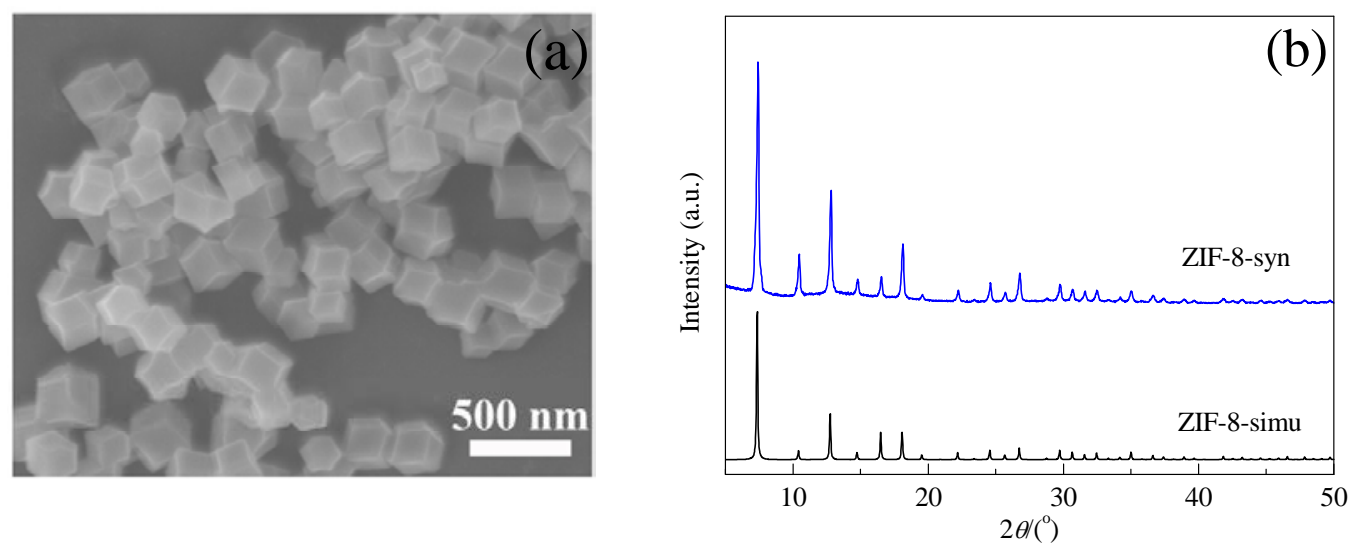

Fig. 1. SEM image (a) and XRD patterns (b) of ZIF-8 crystals.

distance of $0.311 \mathrm{~nm}$, in good agreement with the lattice spacing of the $\{110\}$ plane of $\mathrm{MnO}_{2}$ (Fig. S3(b)). The high-angle annular dark-field scanning transmission electron microscopy (HAADF-STEM) and corresponding elemental mapping images clearly indicated the loading of manganese oxide on ZIF-8 (Fig. S3(c)-(i)). When the second stage of thermolysis was performed at an elevated temperature of $600{ }^{\circ} \mathrm{C}$ under air, $\mathrm{MnO}_{2}$ was reduced to $\mathrm{Mn}_{2} \mathrm{O}_{3}$. Similar phase transformation of $\mathrm{Mn}$ oxides during annealing processes have been reported previously [37,38]; meanwhile, the MOF structure totally collapsed to provide $\mathrm{ZnO}$, which further reacted with $\mathrm{Mn}_{2} \mathrm{O}_{3}$ from $\mathrm{MnO}_{2}$ to form $\mathrm{ZnMn}_{2} \mathrm{O}_{4}$. XRD results indicated that the as-formed material was a mixture of $\mathrm{ZnMn}_{2} \mathrm{O}_{4}$ and $\mathrm{Mn}_{2} \mathrm{O}_{3}$ with manganese oxide being the dominant phase (Fig. 2(a)). To verify the electronic structure and chemical valence of Mn in ZMO, XPS analysis was conducted, as shown in Fig. 2(b) and (c). The XPS survey spectrum confirmed the existence of $\mathrm{Zn}, \mathrm{Mn}$, and $\mathrm{O}$ (Fig. 2(b)). The peaks at 641.7 and $653.5 \mathrm{eV}$ could be assigned to $\mathrm{Mn}$ $2 p_{3 / 2}$ and Mn $2 p_{1 / 2}$, respectively; the binding energy difference of $11.8 \mathrm{eV}$ was consistent with that of $\mathrm{Mn}_{2} \mathrm{O}_{3}$ (Fig. 2(c)). The-
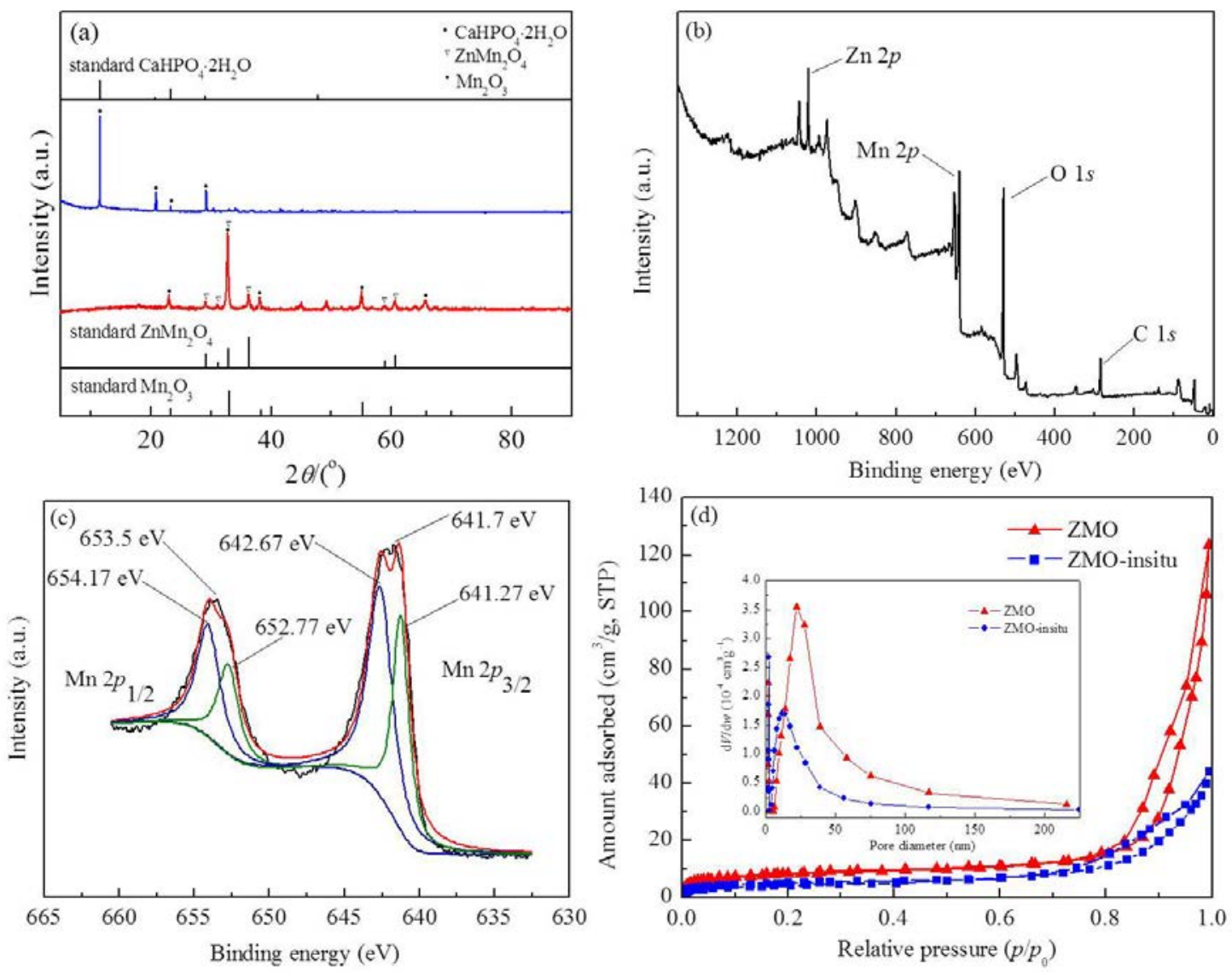

Fig. 2. (a) XRD patterns of ZMO (red line) and ZMO-insitu (blue line); XPS spectra of full scan (b) and Mn $2 p$ region (c) of ZMO; (d) Nitrogen absorption-desorption isotherms and pore size distribution (inset) curves of ZMO and ZMO-insitu. 
peaks at $\sim 1044.57$ and $1021.47 \mathrm{eV}$, attributed to $\mathrm{Zn} 2 p_{1 / 2}$ and $\mathrm{Zn} 2 p_{3 / 2}$, were the characteristics of $\mathrm{Zn}^{2+}$ (Fig. S4); the energy difference of $23.1 \mathrm{eV}$ implied the existence of $\mathrm{ZnMn}_{2} \mathrm{O}_{4}$ phase. Fig. 2(d) shows the $\mathrm{N}_{2}$ adsorption-desorption isotherms of ZMO measured at liquid nitrogen temperature. An obvious hysteresis loop at $p / p_{0}$ of 0.4-1.0 was detected, showing typical type-IV adsorption curves for meso- and/or macroporous structures. The BET surface area of ZMO was measured to be $30.67 \mathrm{~m}^{2} \mathrm{~g}^{-1}$. In addition, results of elemental analysis and AAS measurements for the corresponding materials are listed in Table 1. Both $\mathrm{Zn}$ content and $\mathrm{Zn} / \mathrm{Mn}$ ratio revealed the dominance of $\mathrm{Mn}_{2} \mathrm{O}_{3}$ phase over $\mathrm{ZnMn}_{2} \mathrm{O}_{4}$. The low content of $\mathrm{Zn}$ in this material could be due to easy removal of $\mathrm{ZnO}$ with thermolysis and dissolution treatments.

TEM image of representative ZMO showed irregularly shaped nanoparticles (Fig. 3(a)) with average crystalline size of $30 \pm 5 \mathrm{~nm}$, calculated with the Debye-Scherrer formula $D=$ $\mathrm{k} \lambda / \beta \cos \theta$, where $D$ is the mean crystalline size, $\mathrm{k}$ is the shape factor (0.89), $\lambda$ is the X-ray wavelength (1.543 $\AA$ ), $\beta$ is the full width at half maximum (FWHM) of the corresponding diffraction line, and $\theta$ is the diffraction angle. HRTEM analysis revealed interplanar spacings of 0.247 and $0.272 \mathrm{~nm}$ (Fig. 3(b)), in accordance with the $\{211\}$ plane of $\mathrm{ZnMn}_{2} \mathrm{O}_{4}$ (hetaerolite, JCPDS 24-1133) and \{222\} plane of $\mathrm{Mn}_{2} \mathrm{O}_{3}$ (bixbyite, JCPDS 41-1442). EDX mapping images of ZMO, along with the HAADF-STEM image, confirmed that Mn, Zn, and 0 elements were well-distributed within the material (Fig. 3(c)-(f)).

In addition, a series of $\mathrm{Zn}-\mathrm{Mn}$ oxides was prepared by annealing Mn oxalate-impregnated ZIF-8 under varied conditions.

\section{Table 1}

Characterization results and water oxidation performances of the catalysts.

\begin{tabular}{lcccccc}
\hline Catalyst & $\mathrm{Mn}(\%)$ & $\mathrm{Zn}^{\mathrm{a}}(\%)$ & $\mathrm{O}^{\mathrm{b}}(\%)$ & TON c, e & TOF $^{\mathrm{d}, \mathrm{e}}$ & $\begin{array}{c}A_{\text {BвET }} \\
\left(\mathrm{m}^{2} / \mathrm{g}\right)\end{array}$ \\
\hline $\mathrm{Mn}_{2} \mathrm{O}_{3}$-Syn & $69.60^{\mathrm{f}}$ & 0.00 & 30.40 & 0.042 & 0.023 & 16.82 \\
$\mathrm{Mn}_{2} \mathrm{O}_{3}-1$ & $69.60^{\mathrm{f}}$ & 0.00 & 30.40 & 0.000 & 0.00 & - \\
$\mathrm{Zn}_{x} \mathrm{Mn}_{y} \mathrm{O}_{z}$ & $69.47^{\mathrm{a}}$ & 0.82 & 29.71 & 0.0035 & 0.0020 & - \\
$\mathrm{ZMO}$ & $43.94^{\mathrm{a}}$ & 4.38 & 51.68 & 0.32 & 0.18 & 30.67 \\
\hline
\end{tabular}

${ }^{a}$ Measured by AAS. ${ }^{\mathrm{b}}$ Calculated. ${ }^{\mathrm{c}}$ Defined as moles of evolved $\mathrm{O}_{2}$ in the first 30 min per mole Mn. ${ }^{d}$ Defined as millimoles of evolved $\mathrm{O}_{2}$ in the first 30 min per mole Mn per second ( $\left.\mathrm{mmol}_{02} / \mathrm{mol}_{\mathrm{Mn}} \mathrm{s}\right) .{ }^{\text {e Reaction con- }}$ ditions: $20 \mathrm{mg}$ catalyst; $\left[\mathrm{Ru}(\mathrm{bpy})_{3}\right]^{2+} \quad 2.0 \mathrm{mmol} \mathrm{L}^{-1} ; \mathrm{S}_{2} \mathrm{O}_{8}{ }^{2-} 10.0$ mmol L-1; $\mathrm{Ca}^{2+} 10 \mathrm{mmol} \mathrm{L}^{-1}$; $\mathrm{pH} \sim 7,0.25 \mathrm{~mol} \mathrm{~L}^{-1}$ phosphate buffer; total volume: $100 \mathrm{~mL}$. ${ }^{\mathrm{f}}$ Normalized as the $\mathrm{Mn}$ content in $\mathrm{Mn}_{2} \mathrm{O}_{3}$.

The XRD patterns were all similar to that of ZMO, consisting of a mixture of $\mathrm{Mn}_{2} \mathrm{O}_{3}$ and $\mathrm{ZnMn}_{2} \mathrm{O}_{4}$ phases (Fig. S5). For further comparison, several materials containing $\mathrm{Mn}_{2} \mathrm{O}_{3}$ and/or $\mathrm{Zn}$ ions were synthesized and used for photocatalytic water oxidation. Manganese oxalate was annealed under conditions identical to that of the synthesis of ZMO. The resulting material was well characterized. Its XRD patterns were in agreement with $\mathrm{Mn}_{2} \mathrm{O}_{3}$ (JCPDS 41-1442), and thus this material was denoted $\mathrm{Mn}_{2} \mathrm{O}_{3}-1$ (Fig. S6). Moreover, $\mathrm{Mn}_{2} \mathrm{O}_{3}$ was also prepared through a conventional synthetic method, denoted $\mathrm{Mn}_{2} \mathrm{O}_{3}$-syn. The corresponding physiochemical properties are shown in Tables 1 and S6. When a mixture of zinc nitrate and Mn oxalate was annealed under the same condition, the resulting material was analyzed to contain $\mathrm{Mn}_{2} \mathrm{O}_{3}$ (JCPDS 41-1442) as the dominant
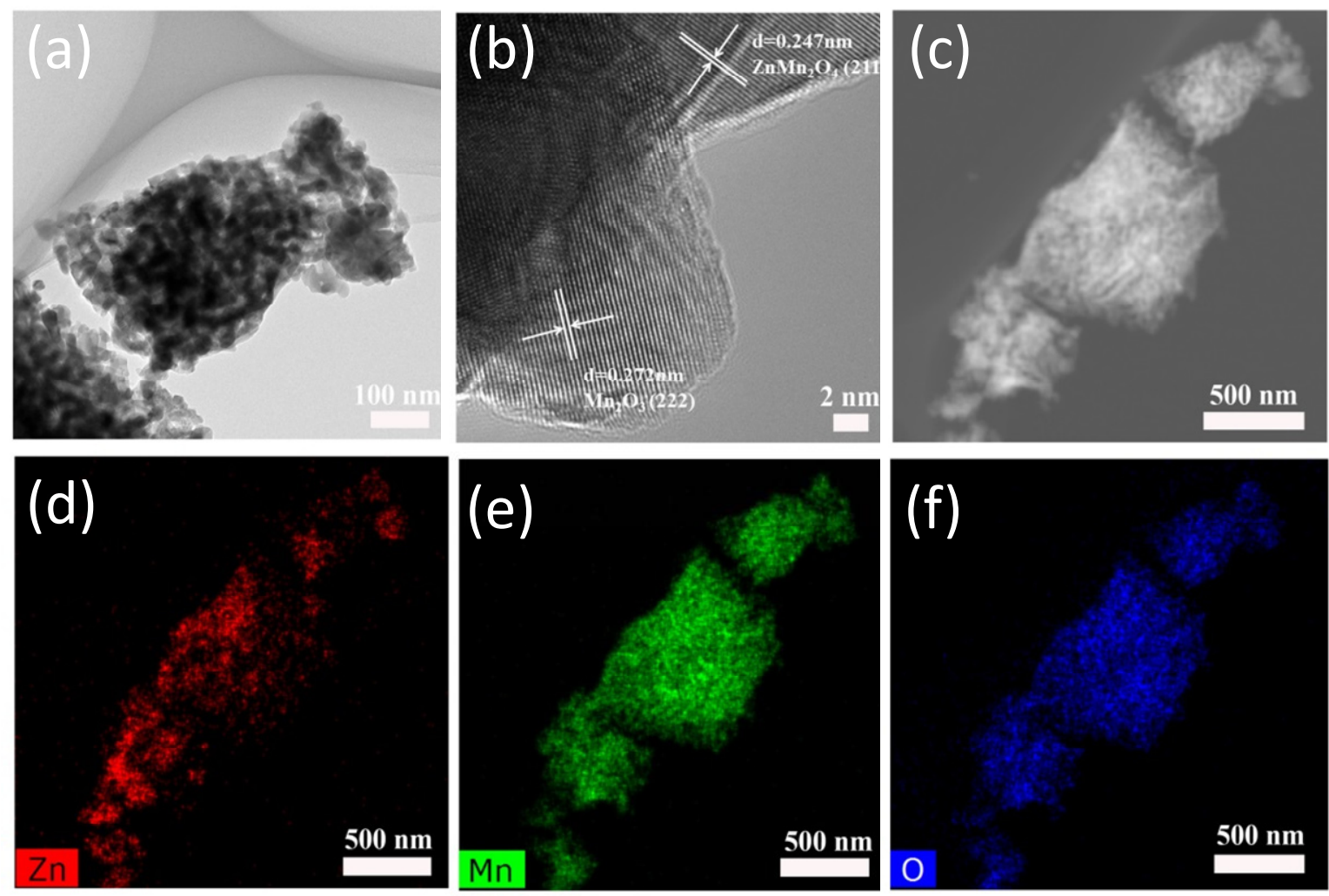

Fig. 3. TEM (a), HRTEM (b), HAADF-STEM (c), and EDX mapping images (d-f) of ZMO. 
phase by XRD analysis and a very small amount of $\mathrm{ZnMn}_{2} \mathrm{O}_{4}$ was also involved (Fig. S6), suggesting that simply annealing a mixture of two metal salts was not a useful strategy for affording Zn-Mn oxides.

\subsection{Photocatalytic water oxidation for $\mathrm{O}_{2}$ evolution and photodeposition of CaP on ZMO}

Light-driven water oxidation reactions were conducted in a well-established $\left[\mathrm{Ru}(\mathrm{bpy})_{3}\right]^{2+}-\mathrm{Na}_{2} \mathrm{~S}_{2} \mathrm{O}_{8}$ system in neutral phosphate buffer aqueous solution, where $\left[\mathrm{Ru}(\mathrm{bpy})_{3}\right]^{2+}$ was excited by irradiation of UV and/or visible light to form its excited radical state, which could be further oxidized by $\mathrm{S}_{2} \mathrm{O}_{8}{ }^{2-}$ to give $\left[\mathrm{Ru}(\mathrm{bpy})_{3}\right]^{3+}$, the primary oxidant participating in ZMO-catalyzed water oxidation [20,39]. Initial assessments demonstrated that the ZMO catalyst, light-irradiation, photosensitizer, and sacrificial electron acceptor were all necessary factors for photocatalytic reaction. In addition, it is known that water oxidation in the $\left[\mathrm{Ru}(\mathrm{bpy})_{3}\right]^{2+-} \mathrm{Na}_{2} \mathrm{~S}_{2} \mathrm{O}_{8}$ system is highly dependent on the $\mathrm{pH}$ value of the applied solution. The oxidant, $\left[\mathrm{Ru}(\mathrm{bpy})_{3}\right]^{3+}$, is more stable under acidic conditions, i.e., $\mathrm{pH}<$ $\sim 4$; whereas under basic conditions, water oxidation activity could be accelerated due to fast reduction of the $\mathrm{Ru}^{3+}$ ion $[20,39]$; besides, natural photosynthesis generates $\mathrm{O}_{2}$ from neutral water. The conditions for ZMO-catalyzed water oxidation were optimized based on the above considerations, including the $\mathrm{pH}$ of the buffer, the concentration of catalyst, the ratio of the photosensitizer versus the electron acceptor, and the methods used in catalyst synthesis (Figs. S7-S12). Under optimized conditions, which were neutral phosphate buffer aqueous solution, $\left[\mathrm{Ru}(\text { bpy })_{3}\right]^{2+}-\mathrm{Na}_{2} \mathrm{~S}_{2} \mathrm{O}_{8}\left(2-10 \mathrm{mmol} \mathrm{L}^{-1}\right)$, and $0.2 \mathrm{~g} \mathrm{~L}^{-1} \mathrm{ZMO}$, the amount of $\mathrm{O}_{2}$ evolved increased approximately linearly for the first $30 \mathrm{~min}$ (Fig. 4); the turnover frequency (TOF) based on the amount of $\mathrm{O}_{2}$ evolved in the first 30 min was calculated to be 0.018 mmolo2 mol $_{\mathrm{Mn}^{-1}} \mathrm{~s}^{-1}$. Interestingly, the catalytic activity could be further enhanced significantly when $10 \mathrm{mmol} \mathrm{L}^{-1}$ calcium triflate was added at the beginning of the above reaction. The highest TOF of $0.18 \mathrm{mmol}_{02}$

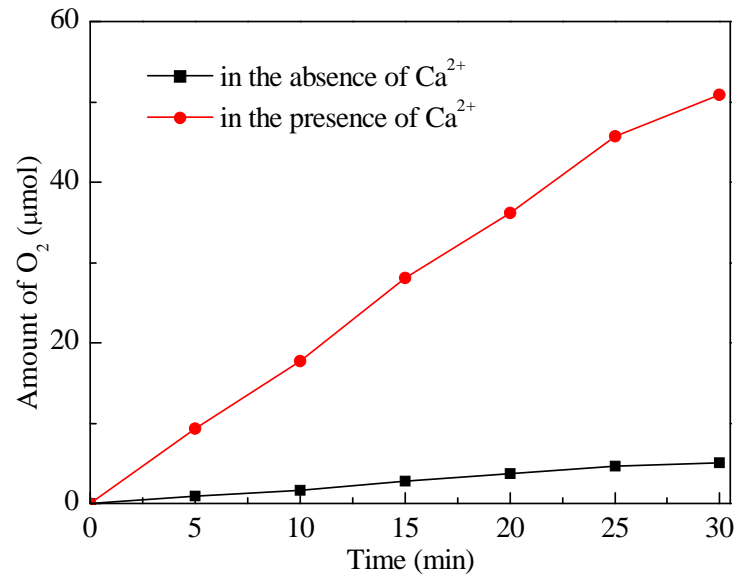

Fig. 4. Time course of $\mathrm{O}_{2}$ evolution in photocatalytic water oxidation using ZMO as photocatalyst in the absence and presence of $\mathrm{Ca}^{2+}(10$ mmol L-1). Reaction conditions: $20 \mathrm{mg} \mathrm{ZMO;}\left[\mathrm{Ru}(\mathrm{bpy})_{3}\right]^{2+} 2.0 \mathrm{mmol} \mathrm{L}^{-1}$; $\mathrm{S}_{2} \mathrm{O}_{8}{ }^{2-} 10.0 \mathrm{mmol} \mathrm{L}-1 ; \mathrm{pH} \sim 7,0.25 \mathrm{~mol} \mathrm{~L}^{-1}$ phosphate buffer; total volume: $100 \mathrm{~mL}$.

molmn $^{-1} \mathrm{~s}^{-1}$ was obtained, 10-fold higher than that of ZMO without $\mathrm{Ca}^{2+}$. Although a similar linear relationship of reaction time versus amount of $\mathrm{O}_{2}$ was detected for the first $25 \mathrm{~min}$, the reaction terminated after 35 min (Fig. 4).

To explore the greatly enhanced water oxidation performance and the role of $\mathrm{Ca}^{2+}$, the final powder, ZMO-insitu, and reaction solution were analyzed. XRD patterns of ZMO-insitu were consistent with $\mathrm{CaHPO}_{4} \cdot 2 \mathrm{H}_{2} \mathrm{O}$ (brushite, JCPDS 09-0077); the peaks for $\mathrm{Mn}_{2} \mathrm{O}_{3}$ and $\mathrm{ZnMn}_{2} \mathrm{O}_{4}$ were almost undetectable, probably owing to the high crystallinity and large amount of CaP formed in situ (Fig. 2(a)). TEM images also confirmed the existence of $\mathrm{CaP}$, showing nanorod crystals of monoclinic brushite wrapping around ZMO (Fig. S13). After washing repeatedly with water and organic solvents, the as-formed free brushite crystals were mostly washed out. The TEM image of ZMO-insitu after washing procedure is shown in Fig. 5(a). The HRTEM image showed lattice spacings of 0.272 and $0.762 \mathrm{~nm}$, which could be assigned to the $\{222\}$ and $\{020\}$ planes of
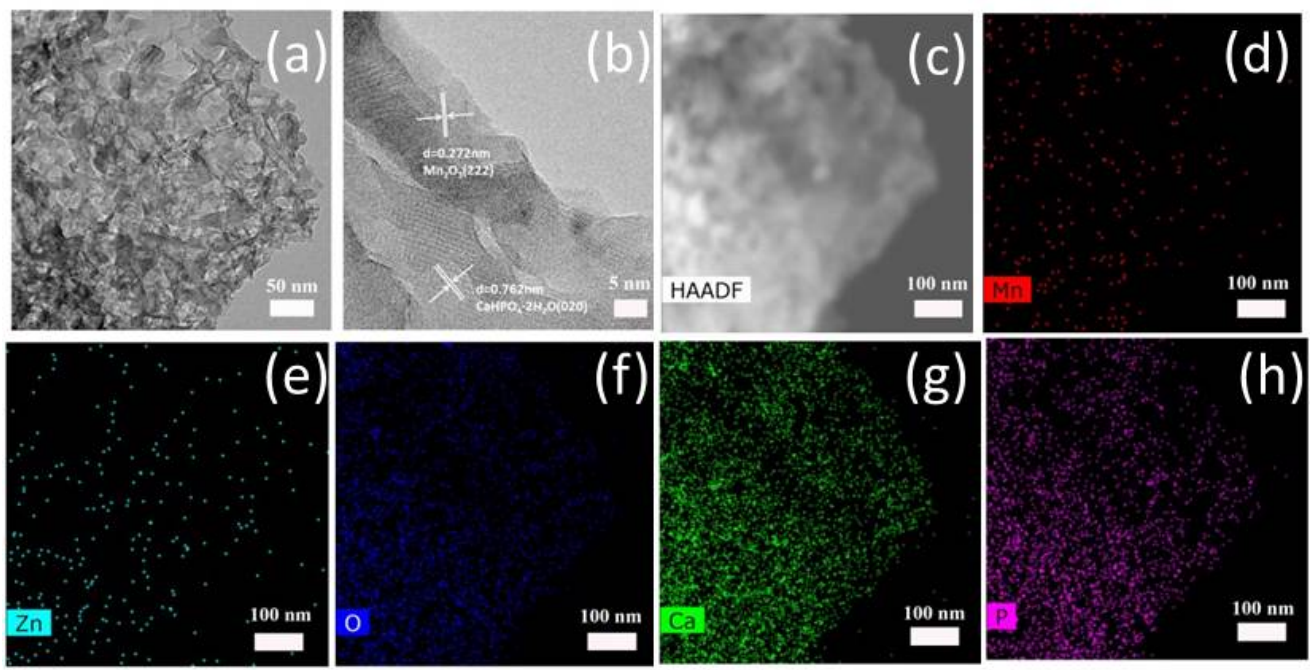

Fig. 5. TEM (a), HRTEM (b), HAADF-STEM (c), and EDX mapping images (d-h) of ZMO-insitu. 
$\mathrm{Mn}_{2} \mathrm{O}_{3}$ (bixbyite) and $\mathrm{CaHPO}_{4} \cdot 2 \mathrm{H}_{2} \mathrm{O}$ (brushite) phases, respectively (Fig. 5(b)). The HAADF-STEM image of the edge of the ZMO particle and the corresponding element mapping results clearly showed the homogeneous distribution of $\mathrm{Mn}, \mathrm{Zn}, \mathrm{O}, \mathrm{Ca}$, and $\mathrm{P}$ elements, indicating that brushite was successfully loaded on the catalyst at high amounts during the photocatalytic reaction (Fig. 5(c)-(h)). The BET surface area decreased significantly to $17.71 \mathrm{~m}^{2} \mathrm{~g}^{-1}$, implying the occupation of CaP on the surface and/or in the pores of ZMO (Fig. 2(d)). These results confirmed in situ doping of CaP on ZMO, which could be the primary reason for the notably promoted photocatalytic activity. However, when ZMO-insitu was used in another reaction cycle of water oxidation, it showed ignorable catalytic activity. The large excess of free CaP could cover the catalytically active sites of ZMO, leading to deactivation of ZMO in the water oxidation reaction. In addition, the $\mathrm{pH}$ of the reaction solution changed slightly to 6.3 after the water oxidation reaction, indicating that phosphate anions $\left(\mathrm{HPO}_{4}{ }^{2-}\right.$ and $\left.\mathrm{H}_{2} \mathrm{PO}_{4}{ }^{-}\right)$acted as proton acceptors; protons were released during the water oxidizing process, and its buffering capacity provided a repair mechanism, similar to the role of Lewis basic amino acids in OEC for proton transport in natural photosynthesis. The decrease in pH may also be related to the consumption of phosphate anion to form CaP in situ.

To verify the influence of irradiation time and loading content of CaP on ZMO-catalyzed water oxidation, a series of control experiments was conducted by varying the important parameters. First of all, the blank test done under optimal experimental condition without the ZMO catalyst showed no photocatalytic activity, although free nanorod crystals of CaP were generated. Second, several CaP@ZMO catalysts were prepared by immersing ZMO in phosphate buffer containing $10 \mathrm{mmol} \mathrm{L}^{-1}$ $\mathrm{Ca}^{2+}$, followed by irradiation with a Xe lamp for a certain time. The resulting powders were collected and washed for further characterization and water oxidation experiments in a $\left[\mathrm{Ru}(\text { bpy })_{3}\right]^{2+-} \mathrm{Na}_{2} \mathrm{~S}_{2} \mathrm{O}_{8}$ system without added $\mathrm{Ca}^{2+}$. The XRD results are shown in Fig. 6. In the case of CaP@ZMO-0, there was neither an obvious peak for $\mathrm{CaP}$ in the XRD analysis nor significant enhancement of catalytic activity in the water oxidation

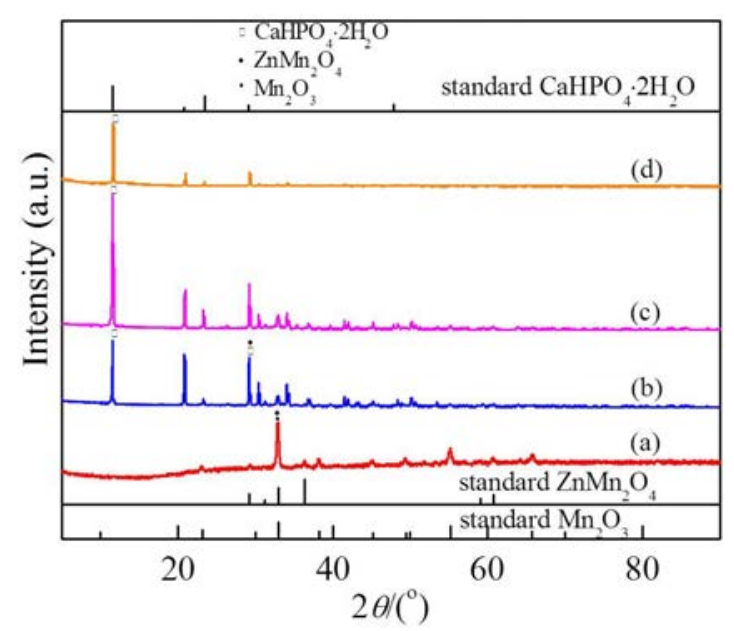

Fig. 6. XRD patterns of CaP@ZMO- $x$, where $x=0$ (a), 15 (b), 30 (c) and 60 (d). reaction; the XRD patterns were mainly attributed to the original ZMO catalyst. This result confirmed that the deposition of CaP on ZMO was actually induced by light irradiation. An increased amount of CaP was detected with increasing irradiation time, which was also consistent with the AAS results (Table S1). The deposition of metal phosphates had been manifested through electronic or thermal treatments previously [40-42].

Accordingly, the photocatalytic activities were enhanced largely by CaP-doping relative to that of bare ZMO. However, the water oxidation performances of the resulting CaP@ZMO- $x$ materials showed a volcano-type relationship with CaP content (Fig. 7). CaP@ZMO-30 was the most active in photocatalytic water oxidation, producing $14.51 \mu \mathrm{mol} \mathrm{O}_{2}$ in the first $30 \mathrm{~min}$. Prolonging the irradiation time to $1 \mathrm{~h}$ could have had a negative effect on the catalytic activity. CaP@ZMO-60 showed almost no activity in water oxidation. The XRD patterns of CaP@ZMO-60 were similar to that of ZMO-insitu with almost no detectable peaks of ZMO (Fig. 6). These results demonstrated that CaP in its free form was inactive in water oxidation reaction, and only those that were deposited on ZMO catalyst were of important for accelerating the water oxidation activity.

Although the total amount of $\mathrm{O}_{2}$ evolved on CaP@ZMO-30 was much less than that of the ZMO doped CaP in situ, it was quite understandable since there was a dynamic equilibrium between $\mathrm{Ca}^{2+}$ and $\mathrm{HPO}_{4}{ }^{2-}$ in the solution and the formation of CaP. Without continuous supply of $\mathrm{Ca}^{2+}$ and $\mathrm{HPO}_{4}{ }^{2-}$, the doped CaP partially dissolved under irradiation during photocatalytic water oxidation, leading to an increase in the concentrations of both the cation and anion in the local microenvironment, which further gathered to form the $\mathrm{Ca}_{3}\left(\mathrm{PO}_{4}\right)_{2} \cdot x \mathrm{H}_{2} \mathrm{O}$ phase in the presence of hydroxide ions derived from water splitting on the surface of ZMO, and thus, hindered $\mathrm{O}_{2}$ formation. The overall reaction is complicated, and some possible reactions are:

$$
\begin{gathered}
\mathrm{H}_{2} \mathrm{O} \rightarrow \mathrm{H}^{+}+\mathrm{OH}^{-} \\
\mathrm{Ca}^{2+}+\mathrm{HPO}_{4}^{2-}+2 \mathrm{H}_{2} \mathrm{O}+h v \rightarrow \mathrm{CaHPO}_{4} \cdot 2 \mathrm{H}_{2} \mathrm{O} \\
\mathrm{CaHPO}_{4} \cdot 2 \mathrm{H}_{2} \mathrm{O} \rightarrow \mathrm{Ca}^{2+}+\mathrm{HPO}_{4}{ }^{2-}+2 \mathrm{H}_{2} \mathrm{O}
\end{gathered}
$$

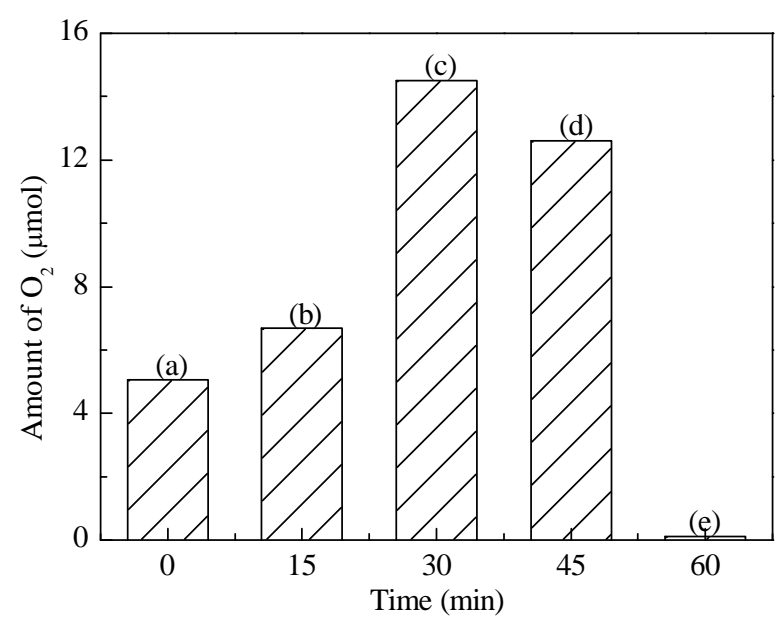

Fig. 7. Water oxidation performance of CaP@ZMO- $x$, where $x=0$ (a), 15 (b), 30 (c), and 60 (d). Reaction conditions: $20 \mathrm{mg}$ ZMO pre-deposited with different amounts of $\mathrm{CaP} ;\left[\mathrm{Ru}(\mathrm{bpy})_{3}\right]^{2+} 2.0 \mathrm{mmol} \mathrm{L}^{-1} ; \mathrm{Na}_{2} \mathrm{~S}_{2} \mathrm{O}_{8} 10.0$ mmol L-1; $\mathrm{pH} \sim 7,0.25 \mathrm{~mol} \mathrm{~L}^{-1}$ phosphate buffer; total volume: $100 \mathrm{~mL}$. 


$$
\begin{gathered}
\mathrm{HPO}_{4}{ }^{2-}+\mathrm{OH}^{-} \rightarrow \mathrm{H}_{2} \mathrm{O}+\mathrm{PO}_{4}^{3-} \\
3 \mathrm{Ca}^{2+}+2 \mathrm{PO}_{4}^{3-}+x \mathrm{H}_{2} \mathrm{O} \rightarrow \mathrm{Ca}_{3}\left(\mathrm{PO}_{4}\right)_{2} \cdot x \mathrm{H}_{2} \mathrm{O}
\end{gathered}
$$

The $\mathrm{Ca}_{3}\left(\mathrm{PO}_{4}\right)_{2} \cdot \mathrm{xH}_{2} \mathrm{O}$ phase was detected in the XRD analysis of CaP@ZMO-30 after one cycle of water oxidation reaction, as shown in Fig. S14, while the patterns of CaP disappeared almost completely. Moreover, the resulting $\mathrm{Ca}_{3}\left(\mathrm{PO}_{4}\right)_{2} \cdot x \mathrm{H}_{2} \mathrm{O}$ loading on ZMO showed negligible impact on accelerating the water oxidation activity of the catalyst, as evident from the amount of evolved $\mathrm{O}_{2}$ in the second reaction cycle of CaP@ZMO-30, which was nearly the same as that of bare ZMO (Table S1).

It was noteworthy that both ZMO-insitu and CaP@ZMOs showed inferior reusabilities because of the large excesses of free CaP covering the active sites of ZMO in the former, and phase-transformation of calcium phosphate in the latter. Further attention to the use of brushite as co-catalyst to boost the photoactivity of a catalyst needs to be paid on changing the balance between the supplementary of calcium salts and the prohibition of undesired phase-transformation of calcium-phosphates.

\subsection{The effect of $\mathrm{Zn}^{2+}$ in photocatalytic water oxidation}

$\mathrm{Zn}^{2+}$ derived from MOF precursor also positively influenced the catalytic activity. When $\mathrm{Mn}_{2} \mathrm{O}_{3}-1, \mathrm{Mn}_{2} \mathrm{O}_{3}$-syn, and $\mathrm{Zn}_{x} \mathrm{Mn}_{y} \mathrm{O}_{z}$ were investigated in photocatalytic water oxidation under identical conditions to those of $\mathrm{ZMO}, \mathrm{Mn}_{2} \mathrm{O}_{3}-1$ was found inactive with no detectable $\mathrm{O}_{2}$ evolution while $\mathrm{Mn}_{2} \mathrm{O}_{3}$-syn and $\mathrm{ZnMnO}_{x}$ were much less efficient catalysts than $\mathrm{ZMO}$ in the presence of $\mathrm{Ca}^{2+}$ (Table 1). Although a series of $\mathrm{Zn}-\mathrm{Mn}$ oxides with different $\mathrm{Zn} / \mathrm{Mn}$ ratios were prepared and used as photocatalysts in water oxidation, the correlation between the activity and the amount of $\mathrm{Zn}^{2+}$ or between the activity and the surface area was not convincing. The photocatalytic activity of this reaction system might be affected by several key parameters including the surface area, the concentration of alkaline metals, and the phase composition of the catalyst. Bringing ZIF-8 in the synthesis of metal oxide could not only afford a material of mixed transition metal oxide with a larger surface area (Table 1) - which counts for better catalytic activity-but also introduce $\mathrm{Zn}^{2+}$ (a weak Lewis acidic metal ion but stronger than $\mathrm{Ca}^{2+}$ ) to the resulting material. It was reported that $\mathrm{Zn}^{2+}$ was able to bind with metal-oxygen complexes, e.g., Fe(IV)-oxo, $\mathrm{Fe}(\mathrm{III})$-peroxo, and Mn(IV)-oxo, and significantly influence the reactivities of electron transfer reactions [43-45]. In addition, introducing a small amount of alkaline metal into the layer matrix between graphene and semiconducting material could facilitate the transfer efficiency of photogenerated charge carriers, leading to significantly improved photoactivity [46]. Since water oxidation reaction proceeds through multiple proton-coupled electron transfer processes, the vital roles of redox-inactive metal ions such as $\mathrm{Zn}^{2+}, \mathrm{Ca}^{2+}$, and $\mathrm{Sr}^{2+}$ in water splitting are highly convincing. Interestingly, considering that $\mathrm{Mn}_{2} \mathrm{O}_{3}-1$ was inactive and ZMO was a mixture of a dominant phase of $\mathrm{Mn}_{2} \mathrm{O}_{3}$ and low amount of $\mathrm{ZnMn}_{2} \mathrm{O}_{4}$ (normalized to the $\mathrm{Zn}$ content in AAS results), the amounts of $\mathrm{Mn}$ in its active form could be distinctly lower than those used in calculating TOFs. Therefore, the actual TOF based on Mn content in the form of

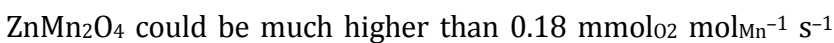
reported here.

\section{Conclusions}

We reported the fabrication of MOF-template zinc manganese oxide and its use in photocatalytic water oxidation in neutral phosphate-buffered aqueous solution containing $\left[\mathrm{Ru}(\mathrm{bpy})_{3}\right]^{2+-} \mathrm{Na}_{2} \mathrm{~S}_{2} \mathrm{O}_{8}$. The water oxidation performance of ZMO could be significantly improved in the presence of calcium ion. A variety of analytical techniques indicated that brushite was doped in situ on ZMO during the water oxidation process, acting as co-catalyst to promote $\mathrm{O}_{2}$ evolution activity. We also discussed the positive influence of $\mathrm{Zn}$ ion derived from ZIF-8 on the photocatalytic water oxidation activity. Our findings demonstrated that calcium phosphate-doped Zn-Mn oxide featured as an effective functional model of the oxygen-evolving complex in photosystem II.

\section{References}

[1] J. Chow, R. J. Kopp, P. R. Portney, Science, 2003, 302, 1528-1531.

[2] N. S. Lewis, D. G. Nocera, Proc. Natl. Acad. Sci. USA, 2006, 103, 15729-15735.

[3] V. Balzani, A. Credi, M. Venturi, ChemSusChem, 2008, 1, 26-58.

[4] N. Armaroli, V. Balzani, Angew. Chem. Int. Ed., 2006, 46, 52-66.

[5] N. S. Lewis, D. G. Nocera, Proc. Natl. Acad. Sci., 2006, 103, 15729-15735.

[6] W. Lubitz, E. J. Reijerse, J. Messinger, Energy Environ. Sci., 2008, 1, 15-31.

[7] L. Hammarström., S. Hammes-Schiffer, Acc. Chem. Res., 2009, 42, 1859-1860.

[8] B. O'regan, M. Gratzel, Nature, 1991, 353, 737-740.

[9] A. Kudo, Y. Miseki, Chem. Soc. Rev., 2009, 38, 253-278.

[10] S. Y. Lee, D. Gonzalez-Flores, J. Ohms, T. Trost, H. Dau, I. Zaharieva, P. Kurz, ChemSusChem, 2014, 7, 3442-3451.

[11] N. Serpone, A. V. Emeline, V. K. Ryabchuk, V. N. Kuznetsov, Y. M. Artem'ev, S. Horikoshi, ACS Energy Lett., 2016, 1, 931-948.

[12] S. Mukhopadhyay, S. K. Mandal, S. Bhaduri, W. H. Armstrong, Chem. Rev., 2004, 104, 3981-4026.

[13] K. N. Ferreira, T. M. Iverson, K. Maghlaoui, J. Barber, S. Iwata, Science, 2004, 303, 1831-1838.

[14] N. S. Lewis, D. G. Nocera, Proc. Natl. Acad. Sci., 2006, 103, 15729-15735.

[15] V. Balzani, A. Credi, M. Venturi, ChemSusChem, 2008, 1, 26-58.

[16] R. Lomoth, A. Magnuson, M. Sjdin, P. Huang, S. Styring, L. Hammarstrm, Photosynth. Res., 2006, 87, 25-40.

[17] C. W. Cady, R. H. Crabtree, G. W. Brudvig, Coord. Chem. Rev., 2008, $252,444-455$.

[18] C. Herrero, B. Lassalle-Kaiser, W. Leibl, A. W. Rutherford, A. Aukauloo, Coord. Chem. Rev., 2008, 252, 456-468.

[19] C. S. Mullins, V. L. Pecoraro, Coord. Chem. Rev., 2008, 252, 416-443.

[20] M. M. Najafpour, G. Renger, M. Hołynska, A. N. Moghaddam, E. M. Aro, R. Carpentier, H. Nishihara, J. J. Eaton-Rye, J. R. Shen, S. I. Allakhverdiev, Chem. Rev., 2016, 116, 2886-2936.

[21] F. Rong, J. Zhao, Z. Chen, Y. X. Xu, Y. P. Zhao, Q. H. Yang, C. Li, J. Mater. Chem. A, 2016, 4, 6585-6594.

[22] M. Wiechen, I. Zaharieva, H. Dau, P. Kurz, Chem. Sci., 2012, 3, 2330-2339. 


\title{
Graphical Abstract
}

Chin. J. Catal., 2018, 39: 1017-1026 doi: 10.1016/S1872-2067(18)63075-X

\section{In situ doping brushite on zinc manganese oxide toward enhanced water oxidation performance: Mimicry of an oxygen-evolving complex}

Miao Jiang, Junying Chen *, Yingwei Li* South China University of Technology

Brushite was in situ doped on MOF-templated zinc-manganese oxide via photodeposition in neutral water containing phosphate and calcium(II) ions, and was responsible for enhanced photocatalytic water oxidation performance.

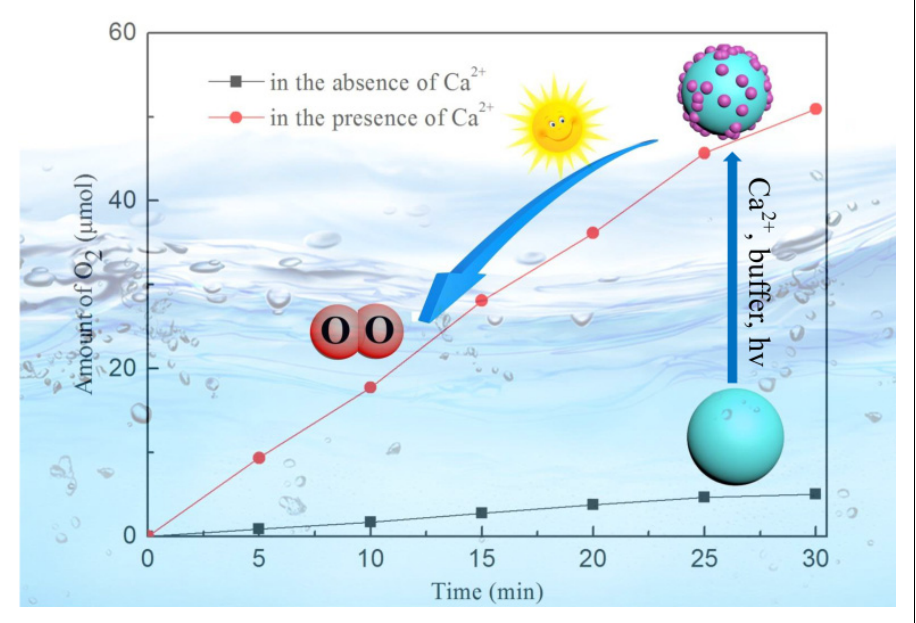

[23] D. Shevchenko, M. F. Anderlund, S. Styring, H. Dau, I. Zaharieva, A. Thapper, Phys. Chem. Chem. Phys., 2014, 16, 11965-11975.

[24] Y. Umena., K. Kawakami, J. R. Shen, N. Kamiya, Nature, 2011, 473, 55-60.

[25] O. M. Yaghi, M. O'Keeffe, N. W. Ockwig, H. K. Chae, M. Eddaoudi, J. Kim, Nature, 2003, 423, 705-714.

[26] G. Férey, C. Mellotdraznieks, C. Serre, F. Millange, J. Dutour, S. Surblé, I. Margiolaki, Chem. Res., 2005, 309, 2040-2042.

[27] D. J. Tranchemontagne, J. L. Mendoza-Cortes, M. O’keeffe, O. M. Yaghi, Chem. Soc. Rev., 2009, 38, 1213-1214.

[28] L. Y. Chen, R. Luque, Y. W. Li, Chem. Soc. Rev., 2017, 46, 4614-4630.

[29] K. Shen, X. D. Chen, J. Y. Chen, Y. W. Li, ACS Catal., 2016, 6, 5887-5903.

[30] W. Chaikittisilp, K. Ariga, Y. Yamauchi, J. Mater. Chem. A, 2012, 1, 14-19.

[31] G. Daculsi, Biomaterials, 1998, 19, 1473-1478.

[32] P. Ducheyne, S. Radin, L. King, J. Biomed. Mater. Res., 1993, 27, 35-45.

[33] L. Chen, H. L. Zhu, S. Yang, B. B. Zhou, F. H. You, X. M. Yan, Mater. Lett., 2015, 143, 252-255.

[34] X. F. Qian, T. Kamegawa, K. Mori, H. X. Li, H. Yamashita, J. Phys. Chem. C, 2013, 117, 19544-19551.
[35] Y. Z. Chen, C. M. Wang, Z. Y. Wu, Y. J. Xiong, Q. Xu, S. H. Yu, H. L. Jiang, Adv. Mater., 2015, 27, 5010-5016.

[36] J. Cao, Y. C. Zhu, K. Y. Bao, L. Shi, S. Z Liu, Y. T. Qian, J. Phys. Chem. C, 2009, 113, 17755-17760.

[37] P. W. Menezes, A. Indra, P. Littlewood, M. Schwarze, C. Göbel, R. Schomacker, M. Driess, ChemSusChem, 2014, 7, 2202-2211.

[38] Q. S. Cao, W. Z. Lu, Z. Y. Zou, G. F. Fan, M. Fu, W. Lei, J. Alloys Compd., 2016, 661, 196-200.

[39] A. R. Parent, R. H. Crabtree, G. W. Brudvig, Chem. Soc. Rev., 2013, 42, 2247-2252.

[40] M. W. Kanan, D. G. Nocera, Science, 2008, 321, 1072-1075.

[41] X. F. Qian, T. Kamegawa, K. Mori, H. X. Li, H. Yamashita, J. Phys. Chem. C, 2013, 117, 19544-19551.

[42] M. Kumar, H. Dasarathy, C. Riley, J. Biomed. Mater. Res., 1999, 45, 302-310.

[43] P. Leeladee, R. A. Baglia, K. A. Prokop, R. Latifi, S. P. de Visser, D. P. Goldberg, J. Am. Chem. Soc., 2012, 134, 10397-10400.

[44] Y. Morimoto, H. Kotani, J. Y. Park, Y. M. Lee, W. W. Nam, S. I. Fukuzumi, J. Am. Chem. Soc., 2011, 133, 403-405.

[45] S. Fukuzumi, K. Ohkubo, Y. M. Lee, W. Nam, Chem. Eur. J., 2015, 21, 17548-17559.

[46] N. Zhang, M. Q. Yang, Z. R. Tang, Y. J. Xu, ACS Nano, 2014, 8, 623-633.

\section{锌锰氧化物原位负载磷酸氢钙以提高水氧化性能: 一种放氧化合物的模型}

\author{
江 沝, 陈俊英 ${ }^{*}$, 李映伟 ${ }^{*}$ \\ 华南理工大学化学与化工学院, 制浆造纸工程国家重点实验室, 广东广州510640
}

摘要: 能源已经成为人类赖以生存和社会发展的物质基础. 随着社会飞速发展和人口迅速增长, 全球能源消耗逐年激增. 资料显示, 天然气、石油、煤这三种化石能源仍然是全球主要能源. 众所周知, 化石燃料不可再生, 已探明储量的化石燃料 仅可供人类使用 $100-200$ 年. 而且, 化石燃料的燃烧会带来严重的环境污染和 $\mathrm{CO}_{2}$ 等温室气体的排放. 这些问题促使人类 寻找开发其它可再生新型能源. 而利用太阳光就是很重要的一个可行方案.

光合作用整个过程主要涉及到光系统I(PS I)和光系统II(PS II). 在PS I中, 太阳光激发后会有一个电子的转移, 使得

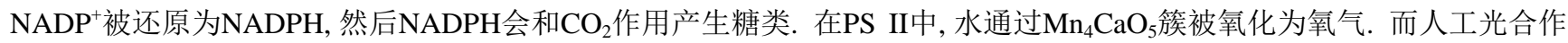


用则是将 $\mathrm{H}_{2} \mathrm{O}$ 和 $\mathrm{CO}_{2}$ 转化为 $\mathrm{O}_{2}$ 和其他含碳化合物或者是直接将 $\mathrm{H}_{2} \mathrm{O}$ 光解为 $\mathrm{H}_{2}$ 和 $\mathrm{O}_{2}$. 通过人工模拟光合作用, 将水裂解为 $\mathrm{H}_{2}$ 和 $\mathrm{O}_{2}$ 被视为更为直观可行的解决能源的方法. 其中, 水氧化是一个复杂缓慢的过程, 也是水全裂解的瓶颈. 因此设计合成 高效水氧化催化剂是提高人工光合作用性能的关键.

自然界光合作用中水氧化反应进行的场所是PSII的放氧复合体(OEC), 其活性中心是被蛋白质环境包围的 $\mathrm{Mn}_{4} \mathrm{CaO}_{5}$ 簇. 2011年, Shen等报道了解相率为 $1.9 \AA$ 的的PS II 的X-射线晶体结构, 在电子密度图上清楚无疑地锁定了 $\mathrm{CaMn}_{4} \mathrm{O}_{5}$ 簇中各个 金属的位置以及它们周围的配体的位置. 三个 Mn、一个Ca、四个O组成一个立方烷的骨架结构, 四号 $\mathrm{Mn}$ 通过氧桥键与立 方烷中的一个 $\mathrm{Mn}$ 原子相连, 该 $\mathrm{Mn}$ 原子上有两个水分子, 另外两个水分子配位在 $\mathrm{Ca}$ 上. 整个 $\mathrm{CaMn}_{4} \mathrm{O}_{5}$ 簇周围的氨基酸起到 了稳定 OEC的作用. 人们一般认为, Mn和Ca是PS II 中WOC必不可少的辅助因子. 大量实验表明, 钻是WOC的功能性和稳 定性中必不可少的存在.

锰和钻不仅在地球上资源丰富, 而且于环境无害, 因此是一种极具吸引力的水氧化催化剂. 基于此, 本文通过焙烧浸 渍锰盐的金属有机骨架材料(MOF), 成功合成出一种锌锰氧化物 (ZMO), 并在含三氟甲磺酸钻的中性磷酸缓冲溶液中进行 的光催化水氧化反应的同时原位负载钻磷石 (CaP), 展现出 $\mathrm{TOF}$ 高达 $0.18 \mathrm{mmol}_{\mathrm{O} 2} \mathrm{~mol}_{\mathrm{Mn}^{-1}} \mathrm{~s}^{-1}$ 的优良性能. 通过X射线粉末衍 射、扫描电镜、透射电镜、原子吸收、 $X$ 射线光电子能谱、热重、 $\mathrm{N}_{2}$ 吸附-脱附等温线等对催化剂的物相、颗粒大小、元 素组成以及比表面积等进行了一系列表征, 证明了 $\mathrm{CaP}$ 作为助催化剂提高了锌锰氧化物的光催化产氧性能. 该催化剂主要 使用了过渡金属锌、锰, 以及䥻元素, 并且在常温和中性条件下使用, 因而可以被视为一种有效模拟OEC的功能型化合物。 关键词：锌锰氧化物; 钻磷石; 金属有机框架; 水氧化; 放氧复合体

收稿日期: 2018-02-04. 接受日期: 2018-03-22. 出版日期: 2018-06-05.

*通讯联系人. 电话: (020)87113656; 电子信箱: chenjunying2010@sina.com

\#通讯联系人. 电话: (020)87113656; 电子信箱: liyw@scut.edu.cn

基金来源：国家自然科学基金(21436005, 21576095, 21706078); 中央高校基本科研业务费(2017PY004, 2017MS088); 制浆造纸工 程国家重点实验室开放基金(201710, 2017ZD04); 中国博士后科学基金(2016M590771，2017T100625); 广东省自然科学基金 (2016A050502004, 2016A030310413, 2017A030310029, 2017A030312005); 广州市科技计划项目 (201804020009).

本文的电子版全文由Elsevier出版社在ScienceDirect上出版(http://www.sciencedirect.com/science/journal/18722067). 